\title{
Association of IL-10 gene polymorphisms and susceptibility to Juvenile Idiopathic Arthritis in Egyptian children and adolescents: a case-control study
}

Manar M. Fathy ${ }^{1 *}$, Hosam F. Elsaadany ${ }^{1}$, Yasser F. Ali ${ }^{1}$, Mohsen A. A. Farghaly², Mohammed E. Hamed ${ }^{1}$, Hany E. Ibrahim', Maha A. Noah¹, Mayy A. N. Allah', Shaimaa S. A. Elashkar', Nasser I. Abdelsalam', Hind M. Abdelrahman ', Ahmed R. Ahmed ', Heba G. Anany ${ }^{1}$, Sanaa M. Ismail ', Boshra R. Ibrahim', Nashwa M. Al Azizi ${ }^{3}$, Heba H. Gawish ${ }^{3}$, Ghada M. Al-Akad ${ }^{3}$, Rehab M. Nabil ${ }^{3}$, Dalia S. Fahmy ${ }^{4}$ and Salah F. Alsayed ${ }^{5}$

\begin{abstract}
Background: Juvenile Idiopathic Arthritis (JIA) is the most common chronic arthritis in children worldwide. Among anti-inflammatory cytokines, interleukin-10 (IL-10) is a key immunosuppressive cytokine involved in the pathogenesis of JIA. To date, only a few studies concerned the association of interleukin-10 gene polymorphisms with JIA. In this study, we aimed to investigate 3 cytokine single-nucleotide polymorphisms situated at positions -1082(G/A), $-819(\mathrm{C} / \mathrm{T})$, and $-592(\mathrm{C} / \mathrm{A})$ in the promoter region of the IL-10 gene to determine whether this polymorphism could be a marker of susceptibility to JIA in Egyptian children and adolescents. We also measured the serum level of IL-10 to assess its relation to such polymorphism.

Methods: This was a case-control study included 100 patients diagnosed with JIA, and matched with age, gender, ethnicity 100 healthy control subjects.

Interleukin-10-1082(G/A), -819(C/T), and -592(C/A) polymorphisms were genotyped by amplification refractory mutation system- polymerase chain reaction (ARMS)-PCR methodology, while the serum IL10 levels were measured by ELISA method.
\end{abstract}

Results: Compared to the controls subjects, the frequency of IL-10- AA genotype and A allele at the -1082 position were overrepresented in patients with JIA $(\mathrm{OR}=2.7 ; 95 \% \mathrm{Cl}: 1.1-6.4$ for the AA genotype; $P<0.05$ and OR: 1.5; 95\% Cl: 1.03-2.3 for the A allele; $P<0.05$ respectively). On the other hand, no significant differences were found between the 2 groups in the genotype or allele frequencies for the -819 and -592 positions. Of note, we found a significant positive association between the IL-10 (-1082) AA genotype and susceptibility to polyarticular JIA (OR: 4.3; 95\% Cl: 1.5-12.7; $P<0.01)$. We observed that patients with the IL-10 (-1082) AA genotype had significantly lower serum IL-10 levels $(2.3 \pm 0.9 \mathrm{pg} / \mathrm{ml})$ compared to those with AG genotype $(7.6 \pm 1.5 \mathrm{pg} / \mathrm{ml})$ and GG genotype $(9.5 \pm 1.2 \mathrm{pg} / \mathrm{ml}) ; P<0.01$, respectively.

Conclusion: We demonstrate for the first time, to the best of our knowledge, that the presence of an A allele or AA gene variant at the -1082 position of the promoter region of the interleukin-10 gene may constitute risk factors for developing JIA in Egyptian children and adolescents. Moreover, we observed a significant positive association between the IL10 -1082 AA gene variant and susceptibility to polyarticular JIA.

Keywords: Juvenile idiopathic arthritis, Gene polymorphisms, Cytokines, Interleukin-10

\footnotetext{
* Correspondence: fzeidan22@yahoo.com

'Department of Pediatrics, Faculty of Medicine, Zagazig University, 13 Omar

Bin Elkhattab St, Al Qawmia, Zagazig City, AlShargia Governorate, Egypt

Full list of author information is available at the end of the article
} 


\section{Background}

Juvenile idiopathic arthritis (JIA) is defined as arthritis in a child under the age of 16 years affecting one or more joints, lasting for at least 6 weeks and currently having no other known etiology [1]. JIA is the most common autoimmune inflammatory joint disease, with an incidence of 2.6 to 23 cases per 100,000 children per year [2]. JIA may lead to long-term morbidities such as uveitis, depression, osteoporosis, poor pain control, and even severe disabilities due to joint damage [3]. The mechanism underlying joint damage in JIA is complex and involves a variety of molecular and cellular processes that may be influenced by genetic factors [4].

Cytokines have been implicated in the development and perpetuation of inflammatory response in JIA [5]. During active disease, cytokine concentrations in plasma of patients with JIA increased 2 to 35-fold [6]. A central feature of JIA is a relative imbalance of cytokine profile, with a relative excess of pro-inflammatory molecules including interleukin-1, interleukin -6 , and tumor necrosis factor (TNF- $\alpha$ ) compared with anti-inflammatory mediators such as interleukin -10 [7]. This idea has raised a great deal of interest in the role of the immunologic system in the pathogenesis of JIA.

Interleukin-10 (IL-10) is a key immunosuppressive cytokine that is produced by a wide range of leukocytes, as well as non-hematopoietic cells [8]. An earlier study by Hart et al. reported that IL-10 can effectively block the production of the pro-inflammatory cytokines IL-1, IL-8, and TNF- $\alpha$ by snivel macrophages and synoviocytes. IL10 was also correlated with an increased autoantibody production and B cell activation in RA patients [9].

Previous studies revealed increased levels in plasma and synovial fluid of some inflammatory cytokines in patients with JIA [10, 11]. Prahalad et al. [10] compared serum cytokine levels between 77 children with different JIA subtypes and 81 age-matched healthy controls. The authors reported that IL10 was significantly elevated in patients with polyarticular as well as systemic JIA. This research added that IL-6 and TNF- $\alpha$ were positively associated with JIA, while IL10 might have a protective effect on disease, as might be anticipated by its inhibitory activity.

Despite these studies, the association of interleukin10 levels with JIA does not constitute proof of cause. One way to clarify the issue of causation involves a genetic approach. The IL-10 gene has been mapped to chromosome 1q31-32, and three single nucleotide polymorphisms (SNPs) in the promoter region at positions $-1082(\mathrm{G} / \mathrm{A}),-819(\mathrm{C} / \mathrm{T})$, and $-592(\mathrm{C} / \mathrm{A})$ have been described [12]. Polymorphisms within genes encoding inflammatory cytokines are known to alter the production of cytokines [13]. To date, only a few studies concerned the association of interleukin-10 gene polymorphisms with JIA and the susceptibility to JIA.

On the basis of these considerations, we designed this study to investigate 3 cytokine single-nucleotide polymorphisms situated at positions $-1082(\mathrm{G} / \mathrm{A}),-819(\mathrm{C} / \mathrm{T})$, and $-592(\mathrm{C} / \mathrm{A})$ in the promoter region of the interleukin10 gene to determine whether this polymorphism could be a marker of susceptibility to JIA in Egyptian children and adolescents. We also measured the serum level of IL10 to assess its relation to such polymorphism.

\section{Methods}

This was a prospective case-control study performed in Zagazig University Hospitals, and outpatient clinics in the same hospitals from April 2014 to October 2016. This study was approved by the ethical committee of Zagazig University, Egypt and written informed consent from parents (and where appropriate patients) was provided in accordance with the Declaration of Helsinki.

One hundred children and adolescents; who had JIA as diagnosed in the Department of Pediatrics in the same hospital, were enrolled in this study. The age of the patients ranged from 9 to 16 years (median, 11 years). Diagnosis of JIA followed the criteria established in the International League of Associations for Rheumatology (ILAR) [14]. Patients were divided into three major subgroups: oligoarticular JIA, polyarticular JIA (including five extended oligoarticular JIA) and systemic JIA. All patients had active disease. Active disease was defined by the presence of joint swelling or limitation of movement with either pain on movement or tenderness [15]. In systemic JIA, fever and laboratory evaluation of erythrocyte sedimentation rate (ESR) and C-reactive protein (CRP) levels were used as additional parameters for disease activity. All patients were subjected to proper history taking placing special focus on number of affected joints, and medications used to treat JIA at the time of enrollment; thorough clinical examination and radiographs were performed to the hands and feet to detect any erosions or joint space narrowing.

One hundred healthy children and adolescents, of comparable age and gender; who attended Pediatric Department for preoperative evaluation for elective surgery, were enrolled as control group. Patients and controls belonged to the same ethnic group: African Caucasian.

\section{Blood sampling}

Blood samples were drawn from all subjects at admission and divided into two portions: $2 \mathrm{ml}$ of whole blood was collected into tubes containing EDTA, for genomic DNA extraction. Serum were separated immediately from remaining part of the sample and stored at $-20{ }^{\circ} \mathrm{C}$ till the time of analysis. 


\section{Genomic DNA extraction}

Genomic DNA from venous blood samples of JIA patients and healthy controls were extracted using a genomic DNA extraction kit (Puregene Blood Kit, Gentra, Valencia, USA) according to the manufacturer's protocol. DNA quantification was done using an Eppendorf Bio Photometer (New York, USA). DNA was stored at $-20^{\circ} \mathrm{C}$.

\section{IL10 genotyping}

All subjects were genotyped for IL10- polymorphism by amplification refractory mutation system (ARMS)-PCR methodology. For the polymorphism at position - 1082 of interleukin-10, a 238 base-pair region was amplified by using the sense primers 5'TTCCCCAGGTAGAGCAAC ACT-3' and the antisense primer 5'GATGGGGTGGA AGAAGTTGAA-3'. For the polymorphisms at positions -819 and -592 of interleukin-10, a 467 base-pair region was amplified using the sense primer 5'AACTTCTTCC ACCCCATCTTT-3' and antisense primer 5'-ATCCTC AAAGTTCCCAAGCAG-3'. as described before [16]. A $25-\mu \mathrm{l}$ PCR reaction mixture contained $10 \mathrm{ng}$ of genomic DNA, $10 \mathrm{pmol}$ of each of $5^{\prime}$-or $3^{\prime}$ - primer, $100 \mu \mathrm{mol} / \mathrm{L}$ $\mathrm{dNTP}, 50 \mathrm{mmol} / \mathrm{L} \mathrm{KCL}, 10 \mathrm{mmol} / \mathrm{L}$ Tris- $\mathrm{HCl}(\mathrm{pH} 8.3)$ $1.5 \mathrm{mmol} / \mathrm{L} \mathrm{Mgcl} 2$ and $1 \mathrm{U}$ of AmpliTaq polymerase. Amplifications were performed using a Perkin-Elmer 2400 thermal cycler according the following parameters: $95{ }^{\circ} \mathrm{C}$ for $3 \mathrm{~min}$ followed by 29 cycles of $95^{\circ} \mathrm{C}$ for $30 \mathrm{~s}, 64{ }^{\circ} \mathrm{C}$ for $20 \mathrm{~s}$, and $72{ }^{\circ} \mathrm{C}$ for $30 \mathrm{~s}$. A final extension at $72{ }^{\circ} \mathrm{C}$ was performed for $10 \mathrm{~min}$. PCR products were digested overnight at $37{ }^{\circ} \mathrm{C}$ using $2.5 \mathrm{U}$ of restriction enzyme. The digested products were analyzed on a $2 \%$ agarose gel stained with ethidium bromide.

\section{Measurement of serum interleukin-10 (IL-10) levels}

IL-10 plasma levels were measured using an enzymelinked immunosorbent assay (ELISA; CLB, Pelikine Compact human IL-10 ELISA kit, Amsterdam, The Netherlands). The sensitivity of the assay was $1 \mathrm{pg} / \mathrm{ml}$ and the assay was performed according to the manufacturer's instructions. The manufacturer reports an intraassay coefficient of variation of less than $10 \%$ and an inter-assay coefficient of variation of less than $10 \%$.

\section{Statistical analysis}

IL-10 genotype and allele frequencies in patients and controls were tested for Hardy-Weinberg equilibrium. Chi-square test was used to determine differences in the frequencies of the different IL-10 genotypes between patients and controls and between clinical subtypes within JIA patients. The odds ratio (OR) and 95\% confidence interval $(95 \% \mathrm{CI})$ were calculated for disease susceptibility and clinical subtypes in relation to the studied IL-10 (SNP) gene polymorphisms. The Student $t$ test and analysis of variance were used to compare numeric variables within groups, depending on the distribution of the data. $P$ value $<0.05$ was considered to be statistically significant. All data were analyzed using the Epi Info statistical software (version 6.2, World Health Organization, Geneva, Switzerland).

\section{Results}

Our study included 100 patients with JIA, their age ranged from 9 to 16 years (median 11 years), 35 males and 65 females and 100 healthy control subjects whose clinical characteristics are listed in Table 1. The control group were age and gender matched to patients with JIA. The mean age at onset of JIA in the patients was 9.7 years and mean disease duration was 3.5 years.

Of these patients, 23 (23\%) had systemic JIA, 31(31\%) had polyarticular JIA (nine patients were RF positive), and $46(46 \%)$ had oligoarticular JIA. On admission, 16\% of JIA patients were receiving a non-steroidal antiinflammatory agent (NSAIDS), 29\% were on NSAIDS and methotrexate(MTX), 28\% were on NSAIDS and steroids, $24 \%$ were on triple therapy of NSAIDS, MTX, steroids, and 3\% were on NSAIDS, MTX, biologic agents (Table 1).

Distribution of IL-10 genotypes, alleles and serum IL-10 levels in patients with JIA and controls are summarized in Table 2. Both groups were in HardyWeinberg equilibrium, with no significant chi-squared values for the observed and expected genotype frequencies.

The IL-10-1082 genotype distribution differed between patients with JIA and healthy controls. The AA

Table 1 Baseline clinical and laboratory data of patients with Juvenile idiopathic arthritis (JIA) and control group

\begin{tabular}{llll}
\hline & $\begin{array}{l}\text { Patients } \\
n=100\end{array}$ & $\begin{array}{l}\text { Controls } \\
n=100\end{array}$ & $P$ \\
\hline Age, years & $7.5(5-16)$ & $7.7(5-16)$ & $>0.05^{\mathrm{a}}$ \\
Gender (M/F) & $35 / 65$ & $39 / 61$ & $>0.05^{\mathrm{b}}$ \\
Subtype of JIA : & & - & - \\
Systemic & $23(23 \%)$ & - & - \\
Polyarticular & $31(31 \%)$ & - & - \\
Oligoarticular & $46(46 \%)$ & & - \\
Age at onset of JIA (years) & $6.7 \pm 1.4$ & - & \\
Medications used on admission & & - & \\
NSAIDS \% alone & $16(16 \%)$ & & \\
NSAIDS, MTX & $29(29 \%)$ & & \\
NSAIDS, steroids & $28(28 \%)$ & & \\
NSAIDS, MTX, steroids & $24(24 \%)$ & & \\
NSAIDS, MTX, biologic & $3(3 \%)$ & & \\
\hline Abbreviations: IL10 intereukin 10 & & & \\
\hline
\end{tabular}

Abbreviations: IL 10 interleukin 10

Data are presented as median (Range) or mean \pm SD

$P$ value $<0.05$ indicates a significant difference

${ }^{\mathrm{a}}$ Mann-Whitney $\mathrm{U}$ test. ${ }^{\mathrm{b}} \mathrm{Chi}$-square test 
Table 2 Distribution of IL-10 genotypes, alleles and serum IL-10 levels in patients with Juvenile idiopathic arthritis (JIA) and control group

\begin{tabular}{|c|c|c|c|c|c|c|c|}
\hline \multirow[t]{2}{*}{ Genotype } & & \multicolumn{2}{|c|}{ Patient group } & \multicolumn{2}{|c|}{ Control group } & \multirow[t]{2}{*}{ OR $(95 \% C l)$} & \multirow[t]{2}{*}{$P$} \\
\hline & & $\mathrm{n}(100)$ & $\%$ & $\mathrm{n}(100)$ & $\%$ & & \\
\hline \multirow[t]{3}{*}{ IL-10 (-1082) } & AA & 23 & $(23)$ & 10 & (10) & $2.7(1.1-6.4)$ & $<0.05$ \\
\hline & $A G$ & 69 & $(69)$ & 73 & (73) & & \\
\hline & GG & 8 & (8) & 17 & (17) & & \\
\hline \multicolumn{8}{|l|}{ Alleles } \\
\hline & A & 115 & $(57.5)$ & 93 & $(46.5)$ & $1.5(1.03-2.3)$ & $<0.05$ \\
\hline & G & 85 & $(42.5)$ & 107 & $(53.5)$ & $0.6(0.4-0.9)$ & \\
\hline \multirow[t]{3}{*}{$-819 /-592$} & TT/AA & 23 & $(23)$ & 19 & (19) & & $>0.05$ \\
\hline & $\mathrm{CT} / \mathrm{CA}$ & 65 & $(65)$ & 71 & (71) & & \\
\hline & $\mathrm{CC} / \mathrm{CC}$ & 12 & (12) & 10 & (10) & & \\
\hline \multicolumn{8}{|l|}{ Alleles } \\
\hline & T/A & 111 & $(55.5)$ & 109 & $(54.5)$ & & $>0.05$ \\
\hline & $C / C$ & 89 & $(44.5)$ & 91 & $(45.5)$ & & \\
\hline Serum IL10 (pg/ml) & & $7.4 \pm 1.5$ & & $5.6 \pm 1.3$ & & & $>0.05^{a}$ \\
\hline
\end{tabular}

Abbreviations: IL-10 interleukin-10, OR odds ratio, Cl 95\% confidence interval Values in parentheses are percentages or data are presented as mean \pm SD

$P$ value $<0.05$ indicates a significant difference. Chi-square test. ${ }^{a}$ Student $t$-test

homozygous genotype was overrepresented (23\%) among JIA patients, compared with controls (10\%). Homozygous subjects had a 2.7 fold increased risk of developing JIA $(\mathrm{OR}=2.7 ; 95 \% \mathrm{CI}: 1.1-6.4 ; P<0.05)$, while genotypes AG/GG were not representative for JIA patients $(\mathrm{OR}=0.37 ; \quad 95 \%$ CI: $\quad 0.15-0.88 ; \quad P \quad<0.05)$; Table 2.

Of note, we found a significant increase in the frequency of the A allele (57.5\%, OR: 1.5; 95\% CI: 1.03-2.3; $P<0.05)$ at the -1082 position in IL-10 gene among JIA patients; where a concomitant significant decrease in the frequency of the $\mathrm{G}$ allele at the same position was observed compared to the control group (42.5\%, OR: 0.6; 95\% CI: 0.4-0.9; $P<0.05$ ); Table 2.

On the other hand, no significant differences were found between the 2 groups in the genotype or allele frequencies for the -819 and -592 positions, which shows linkage disequilibrium; $(P>0.05)$, Table 2 . Complete linkage disequilibrium was observed between the -819 and -592 alleles. All the samples homozygous for allele C at -819 were homozygous for allele $\mathrm{C}$ at -592 , and all the samples homozygous for allele $\mathrm{T}$ at -819 were homozygous for A at -592 ; furthermore, heterozygote samples at position -819 were invariably heterozygous at -592 . Therefore, -819 and -592 genotypes and alleles occurred at identical frequencies (Table 2).

We therefore examined the IL-10 genotypes of the JIA patients with regard to clinical and laboratory parameters. No significant differences were observed when we analyzed IL-10 genotypes according to gender, presence of rheumatoid factor, extra-articular manifestations or mean disease duration.

Our data revealed that patients with JIA had serum IL-10 levels similar to the control group $(7.4 \pm 1.5 \mathrm{pg} / \mathrm{ml}$ vs $5.6 \pm 1.3 \mathrm{pg} / \mathrm{ml} ; P>0.05$ ); Table 2 .

Interestingly, when our patients were evaluated for their clinical subtypes of JIA, there was a significant positive association between the IL-10 (-1082) AA genotype and susceptibility to polyarticular JIA (OR: 4.3; 95\% CI: $1.5-12.7$ for the AA genotype; $P<0.01$ ); Table 3 . On the other hand, no significant association was evident between genotype or allele frequencies for the -819 and -592 positions and different clinical subtypes of JIA among studied patients; Table 3.

We observed that patients with polyarticular JIA did show significantly lower serum IL-10 levels $(2.5 \pm$ $1.3 \mathrm{pg} / \mathrm{ml})$ compared to those with systemic JIA $(5.7 \pm 1.5$ $\mathrm{pg} / \mathrm{ml})$ and patients with oligoarticular JIA $(9.6 \pm 1.7 \mathrm{pg} / \mathrm{ml})$; $P<0.01$, Table 3 .

Of note, we observed that patients with the IL-10 (-1082) AA genotype had significantly lower serum IL-10 levels $(2.3 \pm 0.9 \mathrm{pg} / \mathrm{ml})$ compared to those with AG genotype $(7.6 \pm 1.5 \mathrm{pg} / \mathrm{ml})$ and GG genotype $(9.5 \pm 1.2 \mathrm{pg} / \mathrm{ml})$; $P<0.01$, respectively. The mean serum IL-10 level was $3.5 \pm 0.8 \mathrm{pg} / \mathrm{ml}$ for the A allele vs $10.7 \pm 1.4 \mathrm{pg} / \mathrm{ml}$ for the $G$ allele; $P<0.01$, Table 4 . However, we could not find any significant association between IL-10 genotype or allele frequencies and serum IL-10 levels for the -819 and -592 positions in studied patients with JIA $(P>0.05)$; Table 4 . 
Table 3 Comparison of Genotype and Allele Frequency of IL-10 Polymorphisms between different clinical subtypes of JIA among studied patients

\begin{tabular}{|c|c|c|c|c|c|c|}
\hline \multirow[t]{2}{*}{ Genotype } & & \multirow{2}{*}{$\begin{array}{l}\text { sJIA } \\
n=23(\%)\end{array}$} & \multirow{2}{*}{$\begin{array}{l}\text { polyJIA } \\
n=31(\%)\end{array}$} & oligoJIA & \multirow[t]{2}{*}{$O R(95 \% C l)$} & \multirow[t]{2}{*}{$P$} \\
\hline & & & & $n=46(\%)$ & & \\
\hline \multirow[t]{3}{*}{ IL-10 (-1082) } & $\mathrm{AA}$ & $6(26)$ & $13(42) *$ & $4(9)$ & $4.3(1.5-12.7)$ & $<0.01$ \\
\hline & $A G$ & $16(70)$ & $15(48)$ & $38(82)$ & & \\
\hline & GG & $1(4)$ & $3(10)$ & $4(9)$ & & \\
\hline \multicolumn{7}{|l|}{ Alleles } \\
\hline & A & $28(61)$ & $41(66)$ & $46(50)$ & & $>0.05$ \\
\hline & G & $18(39)$ & $21(34)$ & $46(50)$ & & \\
\hline \multirow[t]{3}{*}{$-819 /-592$} & TT/AA & $5(22)$ & $8(26)$ & $10(22)$ & & $>0.05$ \\
\hline & $\mathrm{CT} / \mathrm{CA}$ & $14(61)$ & $17(55)$ & $34(74)$ & & \\
\hline & $\mathrm{CC} / \mathrm{CC}$ & $4(17)$ & $6(19)$ & $2(4)$ & & \\
\hline \multicolumn{7}{|l|}{ Alleles } \\
\hline & $\mathrm{T} / \mathrm{A}$ & $24(55)$ & $33(54)$ & $54(17)$ & & $>0.05$ \\
\hline & $\mathrm{C} / \mathrm{C}$ & $22(44)$ & $29(45)$ & $38(17)$ & & \\
\hline Serum IL10 (pg/ml) & & $5.7 \pm 1.5$ & $2.5 \pm 1.3$ & $9.6 \pm 1.7$ & & $<0.01^{\circ}$ \\
\hline
\end{tabular}

Abbreviations: IL-10, interleukin-10, sJA systemic Juvenile idiopathic arthritis, poly JIA polyarticular Juvenile idiopathic arthritis, oligo JIA oligoarticular Juvenile idiopathic arthritis, $O R$ odds ratio, $\mathrm{Cl} 95 \%$ confidence interval

Values in parentheses are percentages or data are presented as mean \pm SD

${ }^{*} P$ value $<0.05$ indicates a significant difference. Chi-square test. ${ }^{a}$ ANOVA-test

\section{Discussion}

Juvenile Idiopathic Arthritis (JIA) is the most common chronic arthritis in children worldwide. Children with JIA can experience delayed and restricted growth, with an estimated $49 \%$ of affected children end up with severe functional limitations [17].

A complex interaction between individual gene susceptibility, cytokines activation, and various environmental triggers may lead to an immune imbalance that subsequently results in articular and systemic manifestations of JIA [10]. Cytokines play a pivotal role in immune response

Table 4 Association of IL-10 genotypes and alleles with serum IL-10 levels in patients with JIA

\begin{tabular}{llll}
\hline Gene polymorphism & Genotype/Alleles & Serum $/ \mathrm{L} 10(\mathrm{pg} / \mathrm{ml})$ & $P$ \\
\hline IL-10 (-1082) & AA & $2.3 \pm 0.9$ & $<0.01^{\mathrm{a}}$ \\
& AG & $7.6 \pm 1.5$ & \\
Alleles & GG & $9.5 \pm 1.2$ & \\
& & & $<0.01^{\mathrm{b}}$ \\
& A & $3.5 \pm 0.8$ & \\
IL-10 -819/-592 & G & $10.7 \pm 1.4$ & $>0.05^{\mathrm{a}}$ \\
& TT/AA & $8.4 \pm 1.5$ & \\
& CT/CA & $7.8 \pm 1.7$ & $>0.05^{\mathrm{b}}$ \\
Alleles & CC/CC & $9.7 \pm 1.3$ & \\
\hline
\end{tabular}

Abbreviations: IL 10 interleukin-10

Data are presented as mean \pm SD

$P$ value $<0.05$ indicates a significant difference

${ }^{\mathrm{a}}$ Calculated by ANOVA test ${ }^{\mathrm{b}}$ Student $t$-test and inflammation. Among these cytokines, IL-10 is a potent pleiotropic cytokine that is produced primarily by monocytes and to a lesser extent by Th-2 lymphocytes. This cytokine has the capacity to inhibit the synthesis of pro-inflammatory cytokines such as IL-6, IL-2, IFN- $\gamma$, and TNF- $\alpha$ [18]. An association between the polymorphisms of IL-10 gene and various inflammatory and autoimmune diseases including Juvenile Rheumatoid Arthritis [19], Behcet's disease, non-infectious uveitis, and Type 1 diabetes have been reported [20,21].

Because of potential immune-modulatory effects of IL10 and its importance as a major anti-inflammatory cytokine, IL-10 gene polymorphisms might affect individual susceptibility to JIA.

In the present study, we found that IL-10- AA gene variant and A allele at the -1082 position were overrepresented in patients with JIA compared to the control group. In addition, we observed that individuals with the AA genotype had a 2.7 -fold higher risk for developing JIA, thus revealing that patients were more susceptible to JIA. Furthermore, we detected a significant negative association between JIA and the G allele at the -1082 position (OR: $0.6 ; P<0.05)$ indicating that this association could represent a protective effect against JIA. However, we did not find any significant association between the genotype or allele frequencies and susceptibility to JIA for the -819 and -592 positions of the IL10 promoter regions.

Several recent studies revealed that polymorphisms of various cytokine genes may alter gene expression, and lead to the development of JIA or change its clinical 
manifestations [22-27]. An earlier study by Huizinga et al. [26] reported a lower IL-10 mRNA content in synovial biopsies from adult patients with destructive joint disease compared to those with an inflammatory but non-destructive joint disease. This research revealed that IL-10 promoter genotype could predict joint destruction. The authors added that the presence of the allele associated with less joint destruction was correlated with higher IL-10 production, suggesting a protective role of IL-10 in RA. Crawley et al. [27] demonstrated that patients with juvenile RA with more than four joints affected were more likely to have a particular IL-10 genotype different from those with fewer than four joints affected.

Our study confirm and extend these findings as a significant positive association was evident between the IL-10 (-1082) AA genotype and susceptibility to polyarticular JIA among studied patients (OR: $4.3 ; P<0.01$ ). In addition, we observed that JIA patients with the AA genotype had significantly lower serum IL-10 levels compared to those with the AG and GG genotypes. Furthermore, we found that the A allele at the same position was associated with lower serum IL-10 levels, meanwhile the G allele was correlated with higher IL-10 levels among studied JIA patients. These results were concordant with those of Stanilova et al. [28] who reported that the A to $\mathrm{G}$ switch at position -1082of the IL-10 gene was associated with increased IL-10 production, and the AA, AG, and GG genotypes being associated with low, intermediate, and high interleukin -10 production, respectively.

In accordance with our results, Crawley et al. [27] studied IL10 gene SNPs (at $-1082 \mathrm{~A} / \mathrm{G},-819 \mathrm{C} / \mathrm{T}$, and $-592 \mathrm{~A} / \mathrm{C}$ ) on genomic DNAs of 444 Caucasian children with JIA, compared to 274 healthy control children. The authors found an increased frequency of the ATA haplotype in patients with extended OJIA. They also reported that there is a transcriptional variation in IL-10 production among different genotypes. Their findings confirm an association between the "low" IL-10-producing haplotype and disease severity in children with oligoarticularonset JIA that extends to polyarthritis.

In the current study, no significant association was evident between Il-10 gene variants and susceptibility to systemic onset JIA. By contrast, a study performed by Fife et al. [29] from the UK identified increased prevalence of the IL10-1082 A allele, associated with low IL10 production, in patients with systemic onset JIA. Omoyinmi et al. [30] confirmed that two $I L-10$ genetic variants (rs1878672 and rs1800896) showing some evidence of association with systemic onset JIA in Caucasian population. It may be assumed that interaction between IL10 and other cytokines in antigen presentation and $\mathrm{T}$ cell polarization pathways could determine the phenotype of the disease. Certainly, the small number of studies concerning cytokine gene polymorphisms, particularly in Caucasian population, makes it difficult to express explicitly the hypotheses or concepts.

Experimental models of collagen-induced arthritis revealed that recombinant IL-10 decreases the incidence, delays the onset, and reduces the severity of arthritis [31]. An earlier study by Joosten et al. [32] confirmed that the addition of exogenous IL-10 in these models also had a clear chondroprotective effect. Moreover, synovial tissue cultures indicated that IL-10 functions by inhibition of the production of IL- 1 , TNF- $\alpha$, and matrix metalloproteinases and induces the production of tissue inhibitor of metalloproteinases 1 (TIMP 1). These metalloproteinases are responsible for cartilage degradation. Therefore, a lack of IL-10 can lead to increased expression of metalloproteinases and reduced TIMP 1 expression, allowing joint destruction [33].

Of note, we observed that patients with polyarticular JIA did show significantly lower serum IL-10 levels compared to patients with systemic JIA and those with oligoarticular subtypes. Our results were different from those of Prahalad et al. [10] who reported that IL10 was significantly elevated in polyarticular as well as systemic subtypes of JIA. However, we could not find any significant difference between JIA cases and controls as regards serum IL-10 levels as they did. The systemic concentrations of IL10 are mainly regulated at the level of expression, because IL10 is rapidly cleared from the plasma as it has a plasma half-life of only a few hours [18]. Therefore, this discrepancy may be attributable to methodological issues, such as test specimen (serum versus plasma) and assay methodology or to the differences in the size of the cohorts. However, more studies on cytokine profiles in patients with JIA are needed for a definite conclusion.

On the other hand, no significant association was evident between different clinical subtypes of JIA or serum IL-10 levels and the genotype or allele frequencies for the -819 and -592 positions of the IL-10 promoter regions.

A few studies in the literature concerned the association of human IL-10 gene polymorphisms with JIA and the susceptibility to JIA $[27,29,30,34]$. To our knowledge, ours is the first such study performed in an Egyptian population. However, the small sample size was one of our limitations in this study; we suggest that multicenter approaches may be necessary to attain larger sample size. Cytokine profile was not measured during remission as all studied JIA patients had an active disease. Therefore, the patterns of cytokine expression could not be determined. Another limitation in our study was that IL-10 production may be 
altered in many children with arthritis because of the treatment they receive, which includes both glucocorticoids and MTX; these are both known to affect IL10 production.

\section{Conclusion}

We demonstrate for the first time, to the best of our knowledge, that the presence of an A allele or AA gene variant at the -1082 position of the promoter region of the interleukin-10 gene may constitute risk factors for developing JIA in Egyptian children and adolescents. Moreover, we observed a significant positive association between the IL10 -1082 AA gene variant and susceptibility to polyarticular JIA.

Further studies and more genetic information on ethnicities from different parts of the world will provide an additional understanding of the possible role of cytokine gene polymorphisms in JIA aiming to improve diagnosis, assess severity, and thus seek for new therapeutic modalities of such disease.

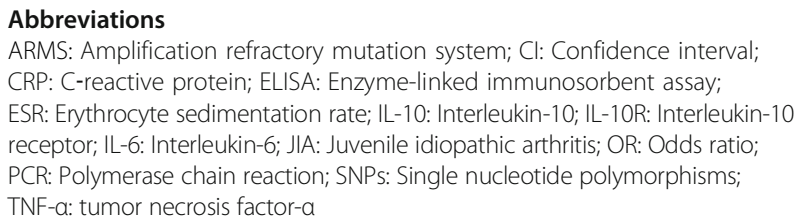

\section{Acknowledgments}

Not applicable.

\section{Availability of data and materials}

All patients' raw data and materials are available at the electronic system of the Zagazig university hospital. Therefore, the data will not be shared.

\section{Funding}

No funds were available for the current research.

\begin{abstract}
Authors' contributions
MMF submitted the manuscript. HFE designed the study. HEI, MANA, SMI and $B R I$ conceived of the study and coordinated the sample collection and data analysis. NIA and HGA participated in the design of the study and, performed the statistical analysis. MEH, MAAF and SSAE wrote the discussion and helped to draft the manuscript. MAN, HMA and ARA critically revised the manuscript and approve final version. NMA, GMA, HHG and RMN performed laboratory analysis and genotyping. DSF, SFA, and YFA reviewed the results, wrote the discussion and approve final version. All authors read and approved all the manuscript.
\end{abstract}

\section{Competing interests}

The authors declare that they have no competing interests.

\section{Consent for publication}

Not applicable.

\section{Ethics approval and consent to participate}

Written informed consent was obtained from all children and adolescents participating in the study, or from their parent or guardian. The study was approved by the Ethics Committee of the Zagazig University, Egypt and the investigation was carried out in accordance with the principles of the Declaration of Helsinki as revised in 1996.

\section{Author details}

'Department of Pediatrics, Faculty of Medicine, Zagazig University, 13 Omar Bin Elkhattab St, Al Qawmia, Zagazig City, AlSharqia Governorate, Egypt. ${ }^{2}$ Department of Pediatrics, Faculty of Medicine, Aswan University, Aswan, Egypt. ${ }^{3}$ Department of Clinical Pathology, Faculty of Medicine, Zagazig University, Zagazig, Egypt. ${ }^{4}$ Department of Rheumatology, Faculty of Medicine, Zagazig University, Zagazig, Egypt. ${ }^{5}$ Department of Internal Medicine, Faculty of Medicine, Zagazig University, Zagazig, Egypt.

Received: 6 November 2016 Accepted: 11 January 2017

Published online: 17 January 2017

\section{References}

1. Petty RE, Southwood TR, Baum J, Bhettay E, Glass DN, Manners P, Maldonado-Cocco J, Suarez-Almazor M, Orozco-Alcala J, Prieur AM. Revision of the proposed classification criteria for juvenile idiopathic arthritis: Durban 1997. J Rheumatol. 1998;25(10):1991-4.

2. Modesto C, Anton J, Rodriguez B, Bou R, Arnal C, Ros J, et al. Incidence and prevalence of juvenile idiopathic arthritis in Catalonia (Spain). Scand J Rheumatol. 2010;39(6):472-9.

3. Weiss JE, llowite N. Juvenile idiopathic arthritis. Rheum Dis Clin North Am. 2007:33(3):441-70.

4. Prahalad S. Genetics of juvenile idiopathic arthritis: an update. Curr Opin Rheumatol. 2004;16:588-94.

5. Woo P. The cytokine network in juvenile chronic arthritis. Rheum Dis Clin North Am. 1997;23(3):491-8. doi:10.1016/50889-857X(05)70344-6.

6. Charo IF, Ransohoff RM. The many roles of chemokines and chemokine receptors in inflammation. N Engl J Med. 2006;354(6):610. 621.

7. Feldmann M, Brennan FM, Maini RN. Rheumatoid arthritis. Cell. 1996;85:307-10.

8. Shouval DS, Ouahed J, Biswas A, Goettel JA, Horwitz BH, Klein C, Muise AM, Snapper SB. Interleukin 10 receptor signaling: master regulator of intestinal mucosal homeostasis in mice and humans. Adv Immunol. 2014;122:177-210.

9. Hart PH, Ahern MJ, Smith MD, Finlay-Jones JJ. Comparison of the suppressive effects of interleukin-10 and interleukin-4 on synovial fluid macrophages and blood monocytes from patients with inflammatory arthritis. Immunology. 1995;84(4):536-42.

10. Prahalad S, Martins TB, Tebo AE, Whiting A, Clifford B, Zeft AS, McNally B, Bohnsack JF, Hill HR. Elevated serum levels of soluble CD154 in children with juvenile idiopathic arthritis. Pediatr Rheumatol Online J. 2008;6:8.

11. Shahin AA, Shaker OG, Kamal N, Hafez HA, Gaber W, Shahin HA. Circulating interleukin-6, soluble interleukin-2 receptors, tumor necrosis factor alpha, and interleukin-10 levels in juvenile chronic arthritis: correlations with soft tissue vascularity assessed by power Doppler sonography. Rheumatol Int. 2002;22(2):84-8. doi:10.1007/s00296-002-0191-1.

12. D'Alfonso S, Rampi M, Rolando V, Giordano M, Momigliano-Richiardi P. New polymorphisms in the IL-10 promoter region. Genes Immun. 2000;1:231-3.

13. Kilpinen S, Huhtala $\mathrm{H}$, Hurme M. The combination of the interleukin-1alpha (IL-1alpha-889) genotype and the interleukin-10 (IL-10 ATA) haplotype is associated with increased interleukin-10 (IL-10) plasma levels in healthy individuals. Eur Cytokine Netw. 2002;13:66-71.

14. Petty RE, Southwood TR, Manners P, Baum J, Glass DN, Goldenberg J, He X, Maldonado-Cocco J, Orozco-Alcala J, Prieur AM, Suarez-Almazor ME, Woo P. International League of Associations for Rheumatology classification of juvenile idiopathic arthritis: second revision, Edmonton, 2001. J Rheumatol. 2004:31(2):390-2.

15. Kamphuis $\mathrm{S}$, Kuis W, de Jager W, Teklenburg G, Massa M, Gordon G, Boerhof M, Rijkers GT, Uiterwaal CS, Otten HG, Sette A, Albani S, Prakken BJ. Tolerogenic immune responses to novel T-cell epitopes from heat-shock protein 60 in juvenile idiopathic arthritis. Lancet. 2005;366(9479):50-6.

16. Perrey C, Turner ST, Pravica V, Howell WM, Hutchinson IV. ARMS-PCR methodologies to determine IL-10, TNF.a, TNF-B and TGF-B1 gene polymorphisms. Transplant Immunol. 1998;7:127-8.

17. Wallace CA, Levinson JE. Juvenile rheumatoid arthritis: outcome and treatment for the 1990s. Rheum Dis Clin North Am. 1991;17:891-905.

18. Sabat R, Grütz G, Warszawska K, Kirsch S, Witte E, Wolk K, Geginat J. Biology of interleukin-10. Cytokine Growth Factor Rev. 2010;21(5):331-44.

19. Lard LR, van Gaalen FA, Schonkeren JJ, Pieterman EJ, Stoeken G, Vos K, Nelissen RG, Westendorp RG, Hoeben RC, Breedveld FC, Toes RE, Huizinga TW. Association of the -2849 interleukin-10 promoter polymorphism with autoantibody production and joint destruction in rheumatoid arthritis. Arthritis Rheum. 2003;48(7):1841-8. 
20. Remmers EF, Cosan F, Kirino Y, Ombrello MJ, Abaci N, Satorius C, Le JM, Yang B, Korman BD, Cakiris A, Aglar O, Emrence Z, Azakli H, Ustek D, TugalTutkun I, Akman-Demir G, Chen W, Amos Cl, Dizon MB, Kose AA, Azizlerli G, Erer B, Brand OJ, Kaklamani VG, Kaklamanis P, Ben-Chetrit E, Stanford M, Fortune F, Ghabra M, Ollier WE, Cho YH, Bang D, O'Shea J, Wallace GR, Gadina M, Kastner DL, Gül A. Genome-wide association study identifies variants in the MHC class I, IL10, and IL23R-IL12RB2 regions associated with Behçet's disease. Nat Genet. 2010;42(8):698-702. doi:10.1038/ng.625. Epub 2010 Jul 11. PubMed PMID: 20622878; PubMed Central PMCID: PMC2923807.

21. Barrett JC, Clayton DG, Concannon P, Akolkar B, Cooper JD, Erlich HA, Julier C, Morahan G, Nerup J, Nierras C, Plagnol V, Pociot F, Schuilenburg H, Smyth DJ, Stevens H, Todd JA, Walker NM, Rich SS, Type 1 Diabetes Genetics Consortium. Genome-wide association study and meta-analysis find that over 40 loci affect risk of type 1 diabetes. Nat Genet. 2009:41 (6):703-7. doi:10.1038/ng.381. Epub 2009 May 10. PubMed PMID: 19430480; PubMed Central PMCID: PMC2889014.

22. Harrison P, Pointon JJ, Chapman K, Roddam A, Wordsworth BP. Interleukin-1 promoter region polymorphism role in rheumatoid arthritis: a meta-analysis of IL-1B-511A/G variant reveals association with rheumatoid arthritis. Rheumatology (Oxford). 2008;47(12):1768-70.

23. Lo SF, Huang CM, Lin HC, Chen WC, Tsai CH, Tsai FJ. Cytokine (IL-6) and chemokine (IL-8) gene polymorphisms among rheumatoid arthritis patients in Taiwan. Clin Exp Rheumatol. 2008;26(4):632-7.

24. Pascual M, Nieto A, Matarán L, Balsa A, Pascual-Salcedo D, Martín J. IL-6 promoter polymorphisms in rheumatoid arthritis. Genes Immun. 2000;1(5):338-40.

25. Pawlik A, Kurzawski M, Drozdzik M, Dziedziejko V, Safranow K, Herczynska M. Interleukin-18 gene (IL18) promoter polymorphisms in patients with rheumatoid arthritis. Scand J Rheumatol. 2009;38(3):159-65.

26. Huizinga TW, Keijsers V, Yanni G, Hall M, Ramage W, Lanchbury J, Pitzalis C, Drossaers-Bakker WK, Westendorp RG, Breedveld FC, Panayi G, Verweij CL. Are differences in interleukin 10 production associated with joint damage? Rheumatology (Oxford). 2000;39(11):1180-8

27. Crawley E, Kay R, Sillibourne J, Patel P, Hutchinson I, Woo P. Polymorphic haplotypes of the interleukin-10 $5^{\prime}$ flanking region determine variable interleukin-10 transcription and are associated with particular phenotypes of juvenile rheumatoid arthritis. Arthritis Rheum. 1999;42(6):1101-8.

28. Stanilova SA, Miteva LD, Karakolev ZT, Stefanov CS. Interleukin-10-1082 promoter polymorphism in association with cytokine production and sepsis susceptibility. Intensive Care Med. 2006:32(2):260-6.

29. Fife MS, Gutierrez A, Ogilvie EM, Stock CJ, Samuel JM, Thomson W, Mack LF, Lewis CM, Woo P. Novel IL10 gene family associations with systemic juvenileidiopathic arthritis. Arthritis Res Ther. 2006;8(5):R148. PubMed PMID: 16959027.

30. Omoyinmi E, Forabosco P, Hamaoui R, Bryant A, Hinks A, Ursu S, et al. Association of the IL-10 Gene Family Locus on Chromosome 1 with Juvenile Idiopathic Arthritis (JIA). PLoS One. 2012;7(10):e47673. doi:10.1371/journal. pone.0047673. Zirlik A, ed

31. Tanaka Y, Otsuka T, Hotokebuchi T, Miyahara H, Nakashima H, Kuga S, et al. Effect of IL-10 on collagen-induced arthritis in mice. Inflamm Res. 1996;45:283-8.

32. Joosten LAB, Lubberts E, Durez P, Helsen MMA, Jacobs MJM, Goldman M, et al. Role of interleukin-4 and interleukin-10 in murine collagen-induced arthritis: protective effect of interleukin-4 and interleukin-10 treatment on cartilage destruction. Arthritis Rheum. 1997:40:249-60.

33. Brennan FM. IL-10 and arthritis. Rheumatology. 1999;38:293-7.

34. MacKay K, Milicic A, Lee D, Tikly M, Laval S, Shatford J, Wordsworth P. Rheumatoid arthritis susceptibility and interleukin 10: a study of two ethnically diverse populations. Rheumatology (Oxford). 2003;42(1):149-53.

\section{Submit your next manuscript to BioMed Central and we will help you at every step:}

- We accept pre-submission inquiries

- Our selector tool helps you to find the most relevant journal

- We provide round the clock customer support

- Convenient online submission

- Thorough peer review

- Inclusion in PubMed and all major indexing services

- Maximum visibility for your research

Submit your manuscript at www.biomedcentral.com/submit
( Biomed Central 